\title{
Aspectos da Adesão Feminina aos Valores Militares: O Casamento e a Família Militar
}

\author{
Aspects of Adhesion of Women to the Military Values: Marriage and Military Family
}

\author{
Maria Cecília de Oliveira ADÃO•
}

\begin{abstract}
Resumo: O artigo aqui apresentado tem como objetivo analisar os níveis de adesão de esposas de oficiais do Exército brasileiro ao projeto profissional de seus maridos. Acreditamos que as mudanças comportamentais femininas, que vêm ocorrendo desde a década de 1960, contribuíram para alterar a maneira como estas mulheres têm se engajado e atendido às necessidades específicas advindas da profissão militar. Neste sentido, percebemos que são diversos os níveis de participação e inserção das esposas na chamada Família Militar, sendo esta uma instância de adesão e manutenção dos valores militares. Utilizando a História Oral como método de recolhimento e análise de entrevistas foi possível dar relevo à ação feminina, por vezes percebida como ausente do fazer histórico.
\end{abstract}

Palavras-chave: Mulheres; Comportamento; Militares; Família Militar; Família.

Abstract: The article presented here aims to analyze the level of adhesion of Brazilian army officers' wives to their husbands' professional projects. We believe that the female behavioral changes, which have occurred since the 1960s, have helped to change the way these women have engaged and fulfilled the needs stemming from the military profession. In this sense, we realize that there are several levels of participation and inclusion of wives in the so-called Military Family which is an instance of adhesion and maintenance of military values. Using Oral History as a method of collection and analysis of interviews, it was possible to give importance to feminine activity, sometimes perceived as absent from the making of history.

Keywords: Women; Behavior; Military; Military Family; Family.

\section{Introdução}

$\mathrm{O}$ artigo aqui apresentado tem como objetivo analisar como tem se dado, nas últimas décadas, a adesão de esposas de oficiais do Exército brasileiro ao projeto profissional de seus maridos.

Acreditamos que os processos de socialização feminino e masculino, realizados até a década de 1960, produziam indivíduos que se identificavam com os estereótipos considerados adequados ao seu grupo sexual. Sendo assim, homens e mulheres internalizavam uma identidade de gênero bastante específica e distinta, que envolvia valores e posturas tidos não só como necessários, mas também como característicos de cada um deles.

As mulheres do período eram socializadas para desempenharem o papel de esposa, mãe e dona-de-casa. Para se tornarem aptas a cumprir estas tarefas, elas eram incentivadas desde a infância a adquirir características tidas como as mais adequadas para o cumprimento da incumbência "que a natureza lhes havia destinado". Portanto, era considerado apropriado que lhes inculcasse a docilidade, o cuidado, a dedicação, a compreensão e a submissão como principais características. Percebemos, também, que este tipo de educação, recebida na família e reforçada

\footnotetext{
- Professora Doutora - Centro Universitário Claretiano - Rua Dom Bosco, 466, CEP: 14300-000, Batatais, SP, Brasil. A pesquisa que resultou neste artigo contou com financiamento da CAPES. E-mail: ceciliaoadao@yahoo.com.br
} 
pela escola, resultava, no momento da profissionalização feminina, em um sentimento de conflito. Sentia a mulher que desempenhava um falso papel, longe do idealmente concebido para a época. Ela esperava que, no momento de seu casamento, pudesse deixar de exercê-lo para voltar a seu lugar de destino.

Resulta disso o casamento visto, pelas mulheres do período, como uma continuação da relação de dependência que mantinham em suas famílias. Uma vez casada, caberia a ela o cumprimento do papel para o qual havia, desde cedo, sido preparada: o de dona-de-casa e mãe.

Concordamos com François de Singly quando este atribui as seguintes características para o grupo familiar formado a partir da situação descrita acima:

Três elementos formam um modelo de referência até hoje pouco contestado: o amor no casamento; a divisão estrita do trabalho entre o homem e a mulher; a atenção à criança, à sua saúde e à educação. Durante meio século (1918-1968), o fato de o homem trabalhar fora para ganhar o dinheiro da família e de a mulher ficar em casa para se ocupar, o melhor possível, dos filhos é uma evidência em todos os meios sociais (SINGLY, 2007, p.130).

No entanto, verificamos que a partir dos anos 1970, sob a influência das mudanças comportamentais empreendidas por uma vanguarda feminina na década anterior, passa a existir uma flexibilização em relação à atitude de gênero, ou seja, uma maior maleabilidade em relação ao que se considera serem características desejáveis para cada grupo sexual. Sendo assim, as mulheres sociabilizadas a partir desse período puderam desenvolver novas posturas e ocupar espaços tidos até então como exclusivamente masculinos. No Brasil, uma das formas de inserção nestes novos espaços é representada pela incorporação feminina às Forças Armadas, que vem ocorrendo desde o ano de 1980.

As mesmas transformações que se imprimiram no processo de socialização feminino, também, deixaram suas marcas no foco de formação dos grupos familiares. Os que foram formados a partir das características do início dos anos 60 são focados nas relações interpessoais, marcadas pela dependência da esposa em relação ao marido e pela permanência dela no lar, visando o cuidado dos filhos. Os que se estabeleceram de acordo com diretrizes das décadas posteriores, têm como característica, que se torna cada vez mais preponderante, a busca da realização pessoal e da satisfação de cada um dos seus membros. Os membros destes grupos apresentam adesão cada vez maior a projetos particulares e sua permanência neles está circunscrita ao período em que suas necessidades e expectativas continuam a ser atendidas.

Tendo como foco o Exército brasileiro e relacionando-o com o acima exposto, consideramos que nesta instituição convivem as duas temporalidades citadas, sendo que a primeira predomina entre as esposas dos oficiais mais antigos, que demonstram um maior nível de adequação ao projeto dos maridos. As mais jovens tendem a adotar uma postura mais flexível, o que resulta em diferentes 
níveis de inserção na Família Militar - sobre a qual falaremos à frente -, e no estabelecimento de relações sociais mais amplas que contribuem para uma maior possibilidade de realização de seus projetos pessoais.

Para a realização do trabalho, utilizamos a História Oral como método de recolhimento e análise da documentação. Esta metodologia é adequada à proposta desta pesquisa porque permite dar relevo à ação de agentes históricos desconsiderados pela historiografia, como é o caso da participação não registrada das mulheres nos diversos aspectos do fazer histórico. Neste sentido, o uso da História Oral nos permite dar voz àqueles que não estão incluídos na História e em sua escrita, o que nos permite dar concretude à história desses grupos. Entrando em contato com seu cotidiano, seus valores, fazeres, suas aspirações, alegrias e frustrações, percebemos que nos deparamos com a dimensão viva da História, que pode ser sentida pessoalmente. (THOMPSON, 1992, p.30.)

Com este objetivo, contamos com a participação de cinco casais militares. Dois deles eram compostos por oficiais superiores (Coronéis) e suas esposas civis, outro por um oficial subalterno (Capitão) e sua esposa, também civil, o quarto era composto por uma oficial subalterna (Capitão) e seu marido, ex-membro do Serviço Temporário do Exército e o último composto por uma oficial subalterna (Tenente) e seu marido (Subtenente). A coleta dos depoimentos foi realizada durante os dias 20, 21 e 22 de janeiro de 2008 na cidade de Brasília ${ }^{1}$, sob a organização do Centro de Comunicação Social do Exército (CECOMSEX). Para proteger as identidades dos entrevistados, os nomes foram trocados.

\section{Os Valores Adquiridos na Formação Militar}

Ao longo de toda sua carreira, um oficial é estimulado a adquirir e internalizar valores que são tidos como essenciais para a formação, dignificação e distinção de um militar. ${ }^{2}$. Dentre estes valores está o respeito pelos princípios da disciplina e hierarquia, tidos como os valores constitutivos ou que sustentam a existência das Forças Armadas ${ }^{3}$.

Durante sua formação, o militar passa por um processo de socialização que podemos considerar constante, e que o leva a diferenciar-se dos outros membros da sociedade. Este processo não cessa no momento de sua saída das academias militares, embora tenha nelas seu período de maior intensidade. Quanto ao seu início, dá-se no momento em que, tornando-se membro constituinte dos quadros de uma academia militar, o aluno passa a pertencer a uma instituição total. Erving Goffman (2003, p.16 e 19) determina que estas, dentre outras características, têm no respeito às normas estabelecidas de relacionamento entre os dirigidos e os dirigentes - aspirantes e oficiais um dos fatores que garantem a continuidade da existência da própria instituição ${ }^{4}$. 
De acordo com Goffman (2003, p.17), na sociedade moderna, os indivíduos dormem, trabalham e brincam em lugares diferentes, convivendo com diferentes tipos de pessoas e de autoridade. Partindo deste parâmetro, o autor caracteriza como aspecto central das instituições totais o rompimento dos limites que separam estas esferas da vida. Em suas palavras:

Em primeiro lugar, todos os aspectos da vida são realizados no mesmo local e sob uma única autoridade. Em segundo lugar, cada fase da atividade diária do participante é realizada na companhia imediata de um grupo relativamente grande de outras pessoas, todas elas tratadas da mesma forma e obrigadas a fazer as mesmas coisas em conjunto. Em terceiro lugar, todas as atividades diárias são rigorosamente estabelecidas em horários, pois uma atividade leva, em tempo predeterminado, à seguinte, e toda a sequência de atividades é imposta de cima, por um sistema de regras formais explícitas e um grupo de funcionários. Finalmente, as várias atividades obrigatórias são reunidas num plano racional único, supostamente planejado para atender aos objetivos oficiais da instituição.

De acordo com o exposto, ao adentrar a Academia Militar das Agulhas Negras (AMAN), o jovem prepara-se para um curso com duração de quatro anos, durante os quais viverá em regime de internato, com saídas periódicas. Ao longo deste tempo, a instituição fornecerá todos os itens necessários para sua permanência. ${ }^{5}$ Já no período inicial, chamado de "período de adaptação", que pode durar de duas a quatro semanas, os alunos ${ }^{6}$ são divididos em grupos de doze, que correspondem aos dormitórios que ocuparão e em pelotões de trinta a trinta e cinco pessoas, sob o comando de um tenente. (CASTRO, 2004, p.19). Esta divisão os induz a deslocarem-se sempre em grupos. ${ }^{7}$ Neste estágio, que se encerra com a matrícula, e após esta, os cadetes terão seus horários rigidamente estabelecidos, com atividades que se estendem das 6 às 22 horas. Suas ações e atitudes também serão reguladas pelas Normas Gerais de Ação (NGA), conjunto de normas que regula as condutas a serem seguidas. De acordo com Celso Castro, "a infinidade de detalhes a serem observados e condutas a serem seguidas constitui uma das maiores dificuldades encontradas pelos novos cadetes." (CASTRO, 2004, p.23).

No que se refere ao "período de adaptação", este é visto por pesquisadores como uma etapa de abrupta e intensa ruptura com os padrões da vida civil, aos quais os alunos estavam acostumados. Nos relatos utilizados por Celso Castro (2004) e Emília Emi Takahashi (2002), a adaptação é tida como uma oportunidade usada, pelos oficiais que comandam os exercícios e treinamentos, para pressionar, ao extremo, tanto física como psicologicamente, os aspirantes. O objetivo seria selecionar aqueles que são capazes de se adaptar à dura e exaustiva vida na academia e "homogeneizar" os alunos, ou seja, ensinar a todos a doutrina e os exercícios militares exigidos, como a "ordem unida." (TAKAHASHI, 2002, p.161)

De acordo com Goffman (2003, p.23 e 25), esta ruptura com a "cultura aparente" advinda do "mundo da família", ou seja, com o padrão da vida civil, é necessária para eliminar "as indicações que revelem o status social (do cadete) no mundo externo". Este status pode ser compreendido 
como "um conjunto de experiências que confirmava uma concepção tolerável do eu e permitia um conjunto de formas de defesa, exercidas de acordo com sua vontade, para enfrentar conflitos, dúvidas e fracassos." A eliminação deste suporte seria caracterizada, dentre outros elementos, pela proibição de saída durante a adaptação, pelo rígido controle dos horários e atividades e pela pressão para tornar o grupo homogêneo, por exemplo, com o uso de uniformes.

Outro fator indicativo do desligamento dos padrões anteriores é a aplicação do termo "bicho" em substituição dos nomes dos cadetes do primeiro ano. Para Goffman (2003, p.27), esta denominação serve para "dar ao novato uma noção clara de sua situação. Como parte de um rito de passagem [...] que lhe diz que tem uma posição baixa nesse grupo...” Esta mesma ideia se aplica ao ritual do trote. A princípio ele é visto como um momento de humilhação e da demonstração da hierarquia entre os alunos. ${ }^{8}$ No entanto, este tem a função positiva de criar um sentimento de pertencimento e comunidade, além de dar ao cadete do primeiro ano a percepção de que sua situação é temporária. Embora não comungue da posição de Goffman sobre serem as academias militares instituições totais, Castro (2004, p.34) confirma a percepção do primeiro ao indicar que:

O trote humilha aquele que almeja um status superior e lhe ensina que, antes de subir, é preciso descer à posição mais baixa. E contribui também para desacreditar qualquer autoestima que o bicho tenha em função de sua vida pregressa e que queira trazer para a vida militar. Reduzidos simbolicamente a um estado préhumano (de "bichos"), os novatos só reencontrarão sua dignidade se estiverem de acordo com as exigências da nova situação de vida a que aspiram.

Consideramos, portanto, que o intenso processo de socialização militar visa romper com a identidade anterior do aluno, mas não somente isso, objetiva também mudar a concepção que ele tem sobre si mesmo e o identificar com uma nova função, um novo papel, considerado mais digno e moralmente superior.

Para adequarem-se a esta nova vida e serem dignificados por meio dela, os alunos das academias militares são induzidos, desde o primeiro momento, a formar ou introjetar o que se convencionou chamar "espírito de corpo". Este pode ser definido como um sentimento de companheirismo e solidariedade que deve acompanhá-los e ampará-los não só durante a estada na academia, mas por toda a carreira militar e que com o tempo, se traduz em apego e zelo por toda a instituição. Este tipo de atitude é bastante valorizado porque ajuda o aluno a suportar e vencer os períodos iniciais, principalmente o de adaptação. Neste momento são comuns as sensações de desamparo pelo afastamento da vida familiar cotidiana, na maior parte das vezes acrescido da distância geográfica, e apreensão quanto ao desempenho e permanência na academia; sentimentos que podem ser minorados pelo apoio mútuo entre os alunos. Segue exemplo:

No EIBM (Estágio de Instrução Básica Militar da Academia da Força Aérea) tem muito espírito de corpo, por exemplo, num corretivo, acho que foi o [...], não 
achava o tênis no quarto e todo mundo do quarto ficou ajudando ele a procurar, aí quando a gente desceu, o cadete do $4^{\circ}$ perguntou o que tinha acontecido e antes da gente começar a pagar, ele perguntou pra turma quem mais era do nosso quarto, aí todo mundo se levantou e só tinha a gente do quarto! Isso marcou. (Cad. Av.) (TAKAHASHI, 2002, p.164) Grifo do autor.

Percebemos que este estado de união e disposição ao apoio mútuo é bastante valorizado na caserna e tido como fundamental para a manutenção de seu funcionamento.

O processo de socialização dos cadetes também envolve a aquisição de outros valores morais que deverão nortear suas ações não só ao longo de sua carreira, mas por toda sua vida, enquanto forem considerados militares, mesmo que não estejam mais no serviço ativo. Oliveiros Ferreira (2000) considera que a busca destes valores é orientada pela "ideia predominante" de honra, que deve acompanhar o militar e promover condutas que o levem a ser considerado digno do oficialato e da defesa da Pátria ${ }^{9}$. Em consonância, Castro (2004, p.44) lista uma série de atributos que, em sua pesquisa, aparecem como sendo valorizados pelos cadetes e que, nesta perspectiva, são por nós considerados complementares e necessários para o exercício da conduta honrosa defendida por Ferreira. Dentre eles podemos citar: seriedade, profissionalismo, competência, maturidade, disciplina e ordem.

É interessante notar, como nos chama a atenção Ferreira, que estes valores devem resultar em "conduta moral e profissional irrepreensíveis", conforme estabelece o Estatuto dos Militares em seu Título II, Capítulo I, Seção II, que versa sobre os deveres militares relacionados à ética. São, portanto, valores cuja busca é incentivada e que devem resultar em ações e atitudes regulamentadas por estatutos de aplicação interna à corporação.

Interessa frisar que à medida que estes valores são internalizados pelos cadetes e passam a orientar suas ações tem início um processo de diferenciação e afastamento do militar do mundo civil. Os valores acima citados começam a ser percebidos pelos futuros militares como opostos às características comumente observadas nos meios civis. Aos civis corresponderiam: falta de seriedade, de profissionalismo, de competência, imaturidade, indisciplina e desordem. Desta diferenciação deriva a distinção claramente perceptível na caserna entre nós-militares e eles-civis. Nesta relação os militares aparecem "classificados" em patamares superiores, quer dizer, são considerados detentores de melhores condições morais que os civis. De acordo com Castro, outros atributos morais percebidos pelos cadetes "reforçam e ampliam aquela fronteira (entre nós-militares e eles-civis), sendo estes, o senso de honestidade e "retidão" de caráter; a preocupação com causas "nobres e elevadas - Pátria, Brasil [...]; o "espírito de renúncia" e o desapego a bens materiais; o respeito à ordem, à disciplina e à hierarquia”. (Castro, 2004, p.44).

Para Ferreira, esta distinção acontece porque os civis orientam-se e estão submetidos apenas às leis nacionais, que regulam o que é legalmente aceito. Ao contrário, os militares se orientariam 
não só pelas leis nacionais, mas também, por normas próprias - como o Estatuto dos Militares, anteriormente citado - aplicáveis apenas aos membros da instituição, que regulam não o que é legal, mas o que é moralmente aceitável. Resulta desta distinção, que em termos comparativos, os militares estariam moralmente em melhor posição, não compreendendo como, no mundo civil, por vezes, o imoral pode ser considerado legal. (FERREIRA, 2000, p.32).

Consideramos, portanto, que o processo de socialização militar visa substituir a identidade anterior do cadete por outra, percebida como mais dignificante e, por isso mesmo, detentora de alto valor positivo e que deve incidir diretamente sobre sua conduta tanto entre seus pares como no mundo civil.

Este processo pode, ainda, ser analisado pela perspectiva da teoria do individualismo. De acordo com ela, vivemos em uma sociedade complexa ${ }^{10}$, que apresenta aos indivíduos oportunidades de realizarem seus projetos ${ }^{11}$ em contextos com diferentes potenciais para individualização ou desindividualização, ou seja, mais ou menos totalizantes. Para que haja projeto, é necessário que o indivíduo possa escolher e orientar-se dentro de “um campo de possibilidades, circunscrito histórica e culturalmente, tanto em termos da própria noção de indivíduo como dos temas, prioridades e paradigmas culturais existentes" 12 (VELHO, 1999, p.27). Deste ponto de vista, quando o cadete opta por pertencer a uma academia militar e tornar-se um oficial, acreditamos que este dá início a um projeto individual que envolve a aquisição das características e valores anteriormente descritos e que se desenvolverá dentro de uma instituição com grande potencial totalizante. Nas palavras de um Subtenente ao referir-se à formação dos cadetes:

\footnotetext{
O que acontece é que mesmo não havendo contato anterior ou militares na família, o contexto onde está inserido aquele que pretende a carreira militar, quando ele busca isso, ele está isolando outras opções de vida: iniciativa privada, curso superior, estágio. Ele está inserido em um grupo muito parecido, porque há muitas semelhanças nesse grupo. Por isso que a unidade se dá tão forte lá dentro, são pessoas que se identificam e são um grupo verdadeiro. Pessoas que se juntam com objetivos comuns. [...] Quando eles se juntam, eles vão com objetivos muito parecidos. Não interessa que não sejam, ainda, militares, mas eles acreditam no valor da carreira militar. ${ }^{13}$
}

Como resultado, uma vez terminado seu processo de profissionalização, o oficial pertencerá a um grupo que possui uma formação com alto grau de especialidade e, também, exigências bastante específicas.

\section{O Casamento como Espaço de Manutenção dos Valores Militares}

É interessante perceber como a ideia de casamento e formação de um núcleo familiar próprio se relaciona com os valores militares. Na percepção do entrevistado acima citado: 
Dificilmente você vai pegar militares ou qualquer outro aluno saído de outra escola que já não vislumbre um casamento, mesmo com vinte e poucos anos de idade. Por quê? Porque nessa profissão eles garantem que são homens formados. [...] E como ser um homem formado se não pensar em família? Entende? São valores, são conceitos que não são originários da instituição militar, mas eles se encontram no grupo dos militares. ${ }^{14}$

Nesta perspectiva, o casamento seria, para o militar, uma forma de reafirmar a eficácia da formação que recebeu e exercitar os valores do grupo. Em outra interpretação, que pode ser vista como complementar, o casamento seria visto como uma possibilidade de receber o apoio necessário para superar as exigências da profissão.

As esposas, normalmente, cooperam sobremaneira. Dificilmente um militar vai passar uma vida e vencer seus desafios profissionais, os seus cursos, o seu caminho de obstáculos - que é natural que existam - se ele não tiver uma companheira. A companheira é uma essência do sucesso das pessoas. ${ }^{15}$

Pensando no acima exposto, qual seria o papel, a participação das mulheres que se casam com oficiais militares? Como elas se encaixariam nas exigências específicas da profissão militar?

Neste sentido, Érica, filha de militar e casada há mais de 20 anos com o Coronel Miranda, quando perguntada sobre como encarava as exigências da vida profissional do marido, nos revela a forma como a dedicação à vida familiar, por parte da mulher, é vista nos meios militares mais antigos ${ }^{16}$ :

Apesar das mudanças, apesar das dificuldades, apesar de abrir mão da tua vida. Você vê que ela (a família) é muito mais importante. Esses laços de família são muito mais fortes do que a sua própria vida. É difícil, muito difícil. Hoje em dia, eu reclamo bastante, sempre reclamei, porque a gente sempre abre mão da sua individualidade em troca da família. ${ }^{17}$

Percebemos então, que em virtude das exigências da profissão militar, as esposas, e neste caso específico a esposa de um oficial superior, estavam dispostas a abrir mão de seus interesses individuais em favor da manutenção da união da família. Do ponto de vista do Coronel Miranda, este tipo de apoio é essencial para o sucesso na carreira militar e na vida familiar:

$\mathrm{O}$ militar com suas particularidades... Eu acho que as mulheres avultam de importância porque, na minha leitura, na minha percepção, como na dos meus companheiros [...] eu noto que as mulheres dão uma contribuição, principalmente, na parte emocional. Elas ajudam muito no sucesso, pela abnegação que elas têm, pelos cuidados que elas têm, principalmente, com os filhos, o cuidado com a casa, com as coisas, com o bem estar da nossa família. Então, essa segurança de retaguarda é uma coisa extraordinária. ${ }^{18}$

Sendo este tipo de apoio visto como fundamental para o sucesso profissional do militar, não seria a escolha de com quem se casar orientada para a consecução deste objetivo? 
Utilizando as declarações de dois dos entrevistados, podemos afirmar que sim. Partindo da observação do Subtenente Martins:

Na verdade, essas coisas não são totalmente acaso. E militares tendem a casar com mulheres que vão justamente trazer essa segurança de uma pessoa no lar. Uma esposa dedicada, coisa dessa natureza. [...] Porque isso vai gerar famílias em moldes muito tradicionais. Vai gerar porque a mulher nunca, nesses casos, foi enganada. 'Não sabia que teria que viajar? Teria que morar numa região de selva?' Isso não acontece. Mas gera uma família bastante tradicional. E que vai resolver aquela questão, também, da família militar, se elas são condizentes ou não. Então, essa mulher inicial é muito interessante, isso é a escolha do sujeito militar pela companheira e ainda mais no início da carreira, quando eles são novos. Isso é muito interessante porque acaba gerando esse modelo super tradicional de família: pai, mãe dona-de-casa, mãe ideal, essas coisas assim. ${ }^{19}$

Casar-se com uma mulher que concorde em zelar pelo lar e pelos filhos, na maior parte das vezes, em detrimento de seus projetos individuais, seria, neste aspecto, a forma ideal de garantir a realização dos objetivos propostos na socialização profissional do militar. Como exemplo, podemos utilizar a necessidade de acompanhar o marido nas transferências pelo território nacional, contingência que seria aceita pelo tipo de esposa acima citado, tido como uma "esposa dedicada".

Outra característica importante da esposa do militar seria a sua capacidade de adequação aos meios militares. Pensando nos valores aprendidos na formação militar, percebemos que estes são os mesmos procurados nestas mulheres. Duas citações são elucidativas deste ponto, partindo da declaração de Moysés, casado com a Capitão Eduarda:

Mas quando eu estava no Exército, que eu era solteiro, não tinha a pretensão de namorar com minha atual esposa, eu sempre tive na cabeça, sempre tive a vontade de namorar uma militar, de ser da mesma profissão, ter os mesmos ideais, ter o mesmo assunto. A gente no Exército, quando está dentro da carreira efetivamente, a gente acaba fazendo um mundo à parte. Então nós aqui dentro somos um mundo e lá fora é o civil. Então, a gente aqui dentro, a maneira de se portar, o comportamento, as conversas, os assuntos, às vezes, até as abreviações que a gente faz, as gírias que a gente usa aqui dentro, se a gente conversar lá fora, as pessoas não entendem, sendo que nós temos que alterar essa conversa. Enquanto isso, quando a gente conversa com qualquer militar, seja mulher, homem, criança, que estão dentro do mundo militar, todos eles entendem o assunto. Então, a gente acaba procurando pessoas da mesma formação. ${ }^{20}$

No que tange esse aspecto, do que se espera da esposa, é que o meio militar, ele é formal. Então, se uma esposa, por exemplo, ela se comporta de uma maneira inadequada, naturalmente, ela vai chamar a atenção. $\mathrm{E}$ as pessoas tendem a se distanciar dela. Essa é a realidade que pode ocorrer. E a inadequação é aquilo que a gente julga que não é uma convivência harmônica. $O$ peso da vestimenta, por exemplo. O palavrão é muito pouco usado no meio social. Uma pessoa que usa palavrão de forma contínua, inadequada ou, às vezes, imprópria, aquilo causa uma consternação. Há sempre uma expectativa da esposa de ela corresponder à semelhança do marido, uma tradição de bom convívio, de um tratamento respeitoso, mas ao mesmo tempo descontraído. Isso não quer dizer que não se brinque, não se sorria muito, não se divirta de todas as formas. Tudo isso dentro de um parâmetro que é aceitável, que é natural, de consideração e de respeito. ${ }^{21}$ 
Portanto, seria esperado que a esposa do militar se comportasse de maneira semelhante ao marido. Um comportamento tido como inadequado ou impróprio por parte dela, seria danoso ao convívio com o restante do grupo, o que por sua vez, poderia vir a prejudicar a ascensão profissional do marido. Neste sentido, uma forma de assegurar esta adequação seria casar-se com uma pessoa anteriormente relacionada ao meio militar. Quando perguntado ao Subtenente Martins se havia, entre seus colegas, uma preferência por casar-se com filhas de militares, a resposta é positiva:

Isso é bastante comum. Não só filhas, às vezes, dentro da instituição-escola, o sujeito casa-se com a irmã do seu melhor amigo. Entende? Mesmo que ela não seja filha de militar, geralmente, é ligada à coisa militar e tem esse respaldo militar. Produz esse sujeito inserido dentro do contexto. ${ }^{22}$

Esta afirmação, de que seria mais comum e interessante para um militar casar-se com uma pessoa já inserida nos meios militares encontra respaldo no nosso universo de entrevistadas. Dentre o universo de esposas entrevistas, $80 \%$ pertencem a este grupo. Érica esclarece: "Eu mesmo já venho de uma vida militar. Então, para mim, é até mais fácil de entender, de conviver, de aceitar este tipo de vida que a gente leva." 23

De outro lado, torna-se importante analisarmos quais motivos levaram as entrevistadas a casar-se com militares. É interessante perceber que entre elas, o fato do marido ser militar foi preponderante na escolha de apenas uma delas. "Como eu venho de um meio militar, eu sempre admirei muito (os militares), sempre gostei muito. E realmente, eu tinha a intenção de casar com um militar." 24

Embora o amor seja apontado como o responsável pelas uniões, todas acreditam que os valores que os militares são incentivados a adquirir em seu processo de socialização contribuem sensivelmente na atração e fortaleceram suas escolhas. ${ }^{25}$ São diversas as características ou atributos citados:

Tudo está dentro de um contexto. Quando você namora, teus valores são diferentes. Você leva muito em consideração os valores, a formação, a seriedade, a postura. Então, o militar desenvolve muito essas características. Então, fica realmente um fator bastante atraente. [...] eles desenvolvem características bastante importantes. [...] os militares parecem ser pessoas mais sérias, mais fortes. Eles te passam uma sensação que você está mais protegida. Então, realmente, eu sempre quis casar com um militar ${ }^{26}$

Eu acredito que tem algumas coisas que sim, que tornam atrativos porque, geralmente, uma pessoa que saiu de casa mais cedo, tem uma certa independência, maior, já sabe fazer as coisas normais da casa. Geralmente, acho que militar não é assim, digamos, filhinho da mamãe, já tem essas características da independência. $\mathrm{Eu}$ acho melhor. Quando a gente conhece uma pessoa que é militar, mesmo sem saber, já há essa característica que fica evidente. ${ }^{27}$ 
[...] a profissão militar, ela tem algumas exigências de comportamento da pessoa. Então, a gente tem disciplina, hierarquia, organização, então essas coisas podem ser atrativos para algumas pessoas. [...] Essas características, de ter organização, essa disciplina, e também, o próprio garbo que a farda impõe. Quando você vê as pessoas fardadas, seja do Exército, da Marinha, da Aeronáutica, parece que aquilo ali dá um atrativo a mais. Eu também falo isso, porque eu também vivi, da época que eu era solteira, morava com meus pais, e eu via muito isso na população feminina da cidade. Os cadetes eram motivos de alvo, era sedutor ver aqueles cadetes fardados, bonitos e tal. Aquele jovem, digamos assim, com um futuro promissor. Então aquilo chamava muito a atenção das meninas. ${ }^{28}$

[...] eles passam uma imagem, não sei se devido ao uso da farda que eles usam. Isso passa uma imagem de cavalheirismo, de poder mesmo, as pessoas têm essa ideia. $^{29}$

Podemos perceber que as características valorizadas - boa formação, valores, seriedade, postura, independência, disciplina, organização - correspondem a fatores de atração que podem ser complementados pela representação de garbo, cavalheirismo, proteção e poder que o porte da farda pode trazer consigo.

Outro fator importante seria a valorização do companheirismo e da formação da família.

Eu não saberia te especificar se seriam melhores pretendentes em detrimento dos civis, mas sem dúvida, eu acredito que a própria questão da disciplina, da compreensão da importância de família que a gente nota, pelo menos no que eu notei [...] contribuem significativamente, porque é uma coisa que nós mulheres acabamos tendo mais um companheiro e não um marido apenas. Também acho que esses fatores contribuem sim. ${ }^{30}$

Um casamento seguro, uma segurança na vida, no dia-a-dia. E acredito que não só o fato de ele ser militar, mas a pessoa com quem ela está casando, também transmita essa segurança para ela. ${ }^{31}$

Acreditamos que, para a sociedade mais ampla, "é o estatuto social de esposa, mais do que o de mãe, que constitui/constrói a diferença feminina como fraqueza e dependência. [...] Este oculta a dependência dos maridos em relação às esposas, invertendo-a, sobretudo, em autoridade e independência". (SARACENO, 1995, p.209). Afastada do mercado de trabalho e resignada ao lar, a mulher se tornaria responsável pela realização das tarefas domésticas, manutenção deste espaço e pelo sucesso de um terceiro, o marido.

Em nossa sociedade, ainda hoje, estas obrigações são consideradas menores ou desqualificadas em relação às atividades econômicas produzidas fora do ambiente doméstico. Neste sentido, a ocupação verdadeiramente importante seria a realizada pelo marido, que promoveria o sustento da família, do qual a mulher estaria dependente. Mesmo que as atividades realizadas por ela viabilizassem o cumprimento das "obrigações masculinas", as primeiras ainda seriam vistas como secundárias em relação às últimas.

No entanto, esta desvalorização do trabalho feminino frente às atividades masculinas não é percebida pelas esposas pertencentes aos meios militares. Embora os "sacrifícios" que fazem em 
favor da carreira do marido sejam evidentes para elas, estes não são vistos como desabonadores. Acreditamos que isto se deve, principalmente ${ }^{32}$, a uma adesão ao projeto profissional do marido. Nas palavras de Carolina:

A esposa de militar, ela tem que ser uma pessoa muito especial, muito desprendida, muito mesmo, em todos os aspectos. Você não pode ter uma vaidade com casa, ser apegada a nada. Você tem que ser totalmente desprendida. Hoje você mora numa casa linda, numa casa imensa, amanhã você está em uma casa pequena e é isso aí. Acho que é amor mesmo, sabe? Amor, amor e amor. É só o que eu defino ser casada com militar. É amor à Nação, amor ao marido. ${ }^{33}$

Portanto, estas esposas sentem-se trabalhando junto com seus maridos no serviço à Nação.

Eu quando... [Risos] Agora eu vou falar que nem aquelas mulheres, 'quando nós fizemos Estado Maior'... [risos] Têm muitos que até mandam fazer um diploma, dão para as esposas... aqueles agradecimentos, placa de prata agradecendo... [risos]. [...] Na verdade, eu sempre falo: o militar realmente é a mulher. Porque quem investe realmente nessa parte somos nós. Nós que estamos ali do lado. É engraçado, eu falo muito isso pro meu marido, é uma das poucas profissões que nós mulheres trabalhamos junto. Nós estamos ali junto. É chazinho, a gente tem que fazer, é jantar, nós vamos junto. É uma profissão que a mulher também está integrada. A única reclamação que eu faço é que nós não temos salário. [risos] A gente devia ganhar muito bem... [risos] E, principalmente, porcentagem de mudança, porque é uma trabalheira. Mas é uma coisa boa. A gente gosta. A gente interage com eles, a gente participa de tudo da vida deles. E eu acho que isso também é bom pra eles, nós estarmos presentes. E acho que isso impulsiona eles a estarem trabalhando. Eu acho que a mulher tem que ser assim a base do lar. Também por eles trabalharem muito. Muitos estão estudando muito, então na maior parte do tempo estão ausentes e a gente que tem que segurar. Mulher de militar segura a barra. Segura mesmo. (SILVA).

Falando sobre a Teoria do Individualismo, Gilberto Velho assinala que: "quanto mais exposto estiver o ator a experiências diversificadas, [...] quanto menos fechada for sua rede de relações ao nível de (sic.) seu cotidiano, mais marcada será a sua autopercepção de individualidade singular. Por sua vez, a essa consciência da individualidade - fabricada dentro de uma experiência cultural específica - corresponderá uma maior elaboração do projeto", ou seja, quanto mais restrita for a rede de relações, menos individualista será o projeto. As palavras do Subtenente Martins ilustram essa afirmação:

Agora tenho que ver... Tentar ver esse lado da mulher que se casa com um militar. É, mais uma vez tem que se destacar o que é da cultura da comunidade do que da cultura de um grande centro. Tudo tem que ficar bem caracterizado. Por que eu falo isso? Eu acho que pela educação, pelo que é dado num grande centro, aquilo que uma mulher já independente - vamos dizer assim: já dona do seu futuro, estudando, trabalhando - tem como visão de sociedade é diferente daquela mulher que está morando com os pais ou com certo rigor de alguns conceitos tradicionais de família. São coisas diferentes. ${ }^{34}$

Sendo assim, consideramos que alguns fatores se conjugam para explicar a adesão das esposas ao projeto do marido. No nosso universo de entrevistadas, $80 \%$ das esposas são filhas de militares, 
o que possibilitou que estas tivessem um contato anterior com o meio em que seus maridos estão inseridos. Desde a infância, acostumaram-se a constantes mudanças e à valorização do núcleo familiar a que pertenciam. Além disso, admiram e adotam os mesmos valores ensinados durante o processo de socialização militar ${ }^{35}$. Nas palavras da Capitão Eduarda:

No meu caso, eu sou de uma família de praticamente militares. Meu pai era militar, meu irmão é militar, eu entrei na carreira militar, a minha irmã mais nova também entrou na carreira militar, a irmã do meio é casada com militar. Então, eu convivi sempre com isso, a respeitar todas as coisas que envolvem a carreira e conhecer melhor. Eu tive a oportunidade, que um civil não tem, de conhecer melhor essa vida. Então, eu admiro muitas coisas que os militares passam. ${ }^{36}$

Podemos perceber que, nos meios militares, existe uma adesão, tanto por parte dos homens quanto das mulheres, aos valores que os oficiais são estimulados a adquirir em seu processo de socialização profissional. Esta adesão leva à formação de casais que passam a ter um projeto comum, que se realiza por meio da carreira do marido ou, no caso das mais jovens, no ingresso na profissão militar. Ainda assim, e neste sentido, ambos reconhecem que o papel desempenhado pela esposa - dar apoio, cuidar dos filhos e do lar, na maior parte das vezes, abdicando de projetos pessoais - é fundamental para o sucesso desta empreitada. Esta percepção é fundamental para que a esposa sinta-se valorizada, gratificando-a pelos sacrifícios pessoais realizados.

\section{O Papel da "Família Militar" na Manutenção dos Valores Militares}

A principal dificuldade destacada pelas esposas é a adaptação às constantes transferências que o militar de carreira está sujeito e que implicam em mudanças constantes para diferentes cidades, estados e em alguns casos, para o exterior. Para a família, estas movimentações implicam em distanciamento geográfico do núcleo familiar original, o que impede que usufruam da solidariedade parental, e em dificuldades para manter laços de amizade construídos nas localidades onde viveram. Para os filhos, resultam em constantes transferências de escola e para a esposa em uma impossibilidade de manter longos vínculos empregatícios ou de concluir cursos universitários. De acordo com as entrevistadas estes são os principais obstáculos.

Eu tenho uma visão assim, porque como eu fui filha de militar, a minha mãe foi uma pessoa que acompanhou sempre meu pai. E a minha mãe não trabalhava por conta disso, ela teve quatro filhos e não tinha como trabalhar. [...] Então, ela foi uma pessoa assim, que dedicou a vida dela à casa, aos filhos e à profissão do esposo praticamente. ${ }^{37}$

Isso realmente é muito difícil, porque é uma renúncia da vida profissional da esposa. Exige mesmo muito amor, muita dedicação. Porque as constantes mudanças, isso aí altera na família todinha. Não só a esposa, a profissão dela, os filhos, tudo. ${ }^{38}$ 
É muito difícil, especialmente quando você tem filhos, porque você acaba tendo um impacto muito grande no sentido de círculos de amizade, no sentido de empregabilidade, de estudos, principalmente de estudos, quando você já tem um filho na faculdade ou que a esposa ainda faz. Então acaba sendo bastante sacrificante para $\mathrm{o}$ aspecto de estrutura de família. ${ }^{39}$

É difícil. Muito difícil. Hoje em dia, eu reclamo bastante, sempre reclamei, porque a gente sempre abre mão da sua individualidade em troca da família. E, principalmente, o militar... em que você está trabalhando, como é o meu caso, porque mudou e tem que começar tudo de novo. E daqui dois anos está mudando de novo. Dificuldades com filhos. Então é uma causa bastante difícil essa. ${ }^{40}$

Mudando-se constantemente, em alguns casos mais de uma vez ao ano ${ }^{41}$, e impedidas de estabelecerem laços de solidariedade mais duradouros nas localidades onde residem, as famílias buscam apoio em outras famílias compostas por militares e que compartilham a mesma situação. Esta união passa a compor a chamada "Família Militar", uma rede de apoio e solidariedade na qual, principalmente as mulheres podem se estribar.

Então o que a gente faz? A gente se ajuda. Uma depende da outra pra um quebra galho, uma festinha, filho doente. A gente fala que é a Família Militar. E é verdade. Uma ajuda a outra. Tem esse lado muito bom. E o melhor ainda é quando depois de muitos anos nós vamos encontrar as mesmas amigas, de quando o filho era pequeno, de quando nasceu o neném e ela ajudou. E isso é bom. [...] Porque a gente passa a maior parte das nossas vidas em contato com esses amigos, e não com o mundo familiar. (SILVA, p.07).

O que acontece é que as mulheres dos militares, diferente de alguns outros trabalhos, a gente convive, tem o que a gente chama de Família Militar. Até em função de você sair de onde está morando, para ir para uma outra determinada região, morar em uma vila em que é todo mundo militar. [...] Acaba criando um vínculo muito forte com as outras mulheres que estão na mesma situação, lá no local. É a família que você tem para viver. ${ }^{42}$

Esta Família se consolida tanto por meio de ajuda mútua em casos de dificuldades - por exemplo, auxílio com um filho doente - como por meio de festas e celebrações. Consideramos que esta forma de solidariedade seria correspondente ao "espírito de corpo" que os oficiais são incentivados a desenvolver durante sua profissionalização. Como neste caso, a participação na Família Militar resulta, para o núcleo familiar, em apego e zelo pelos valores ensinados na caserna. Neste sentido, é interessante perceber que existe, por parte da instituição, um incentivo à integração de seus membros nesta grande família. A pesquisa conduzida por Fernanda Chinelli ilustra essa situação:

Além dos eventos patrocinados pelo Exército (como o "Baile de Boas Vindas" para os novos alunos e o "Baile das Nações"), existe a atribuição de cargos às esposas, objetivando a integração entre os oficiais e suas famílias. O cargo de "xerife da turma", conferido à esposa do "xerife da turma da Eceme" (o aluno mais antigo, cuja função é representar a turma), é um exemplo deste movimento de integração. A "xerife" é apresentada no evento oficial de boas vindas às famílias, cabendo-lhe 
a responsabilidade de organizar atividades coletivas reunindo as demais esposas. (SILVA, p.07).

Além de possibilitar o apoio mútuo, o pertencimento a este grupo, como vimos acima, acarreta um engajamento nas atividades coletivas. ${ }^{43}$ Embora a participação não seja obrigatória, espera-se, principalmente das esposas de oficiais superiores, que tomem parte neste convívio social. Nas explicações da Tenente Camila e do Coronel Oliveira:

Então, principalmente a esposa de comandante tem esse papel de esposa do militar, esposa do comandante, de reunir as esposas, trabalhar numas obras sociais, como as primeiras-damas, coisa parecida. ${ }^{44}$

[...] eu acredito que não é um papel estipulado. Se você for designado, por exemplo, como tenente para comandar um pelotão de fronteira, você é casado, sua esposa está ao seu lado. Lá você tem um papel social relevante. Ela, por sua vez, na área das mulheres, na área feminina, também, mas isso não é estipulado, ela necessariamente não tem que fazer. ${ }^{45}$

Diante do exposto, podemos perceber que a Família Militar corresponde a um projeto social nos moldes que Gilberto Velho (1999, p.33) indica:

A possibilidade de formação de grupos de indivíduos com um projeto social que englobe, sintetize ou incorpore os diferentes projetos individuais, depende de uma percepção e vivência de interesses comuns que podem ser os mais variados [...] classe social, grupo étnico, grupo de status, família, religião, vizinhança, ocupação, partido político etc. A estabilidade e a continuidade desses projetos supraindividuais dependerão de sua capacidade de estabelecer uma definição de realidade convincente, coerente e gratificante.

Temos, portanto, um grupo formado por indivíduos com projetos e vivências comuns, cuja gratificação passa pela manutenção dos valores militares, pela ascensão profissional do marido e por um sentimento de pertencimento a uma instituição nacionalmente respeitada. $\mathrm{O}$ depoimento a seguir ilustra com excelência este ponto.

Bisneta, neta, filha e esposa de militar, estou bem familiarizada com os problemas inerentes à Caserna. Sei o que o militar, apesar de ter uma vida profissional extremamente agradável, considerando o relacionamento dos integrantes da carreira que até denominaram de a "família militar"; de ter amigos tão sinceros que chega até a causar inveja ao pessoal civil; de ter uma boa noção do que é correto e ético permitindo-lhe um sono tranquilo; de ter o respeito de grande parte da população que sempre considera e elege as Forças Armadas como a instituição mais respeitável; enfrenta-se dificuldades que só nós da "família" conhecemos(CARVALHO, 2008, p.118).

Este mesmo grupo pode exercer funções de regulamentação das ações e atitudes de seus membros, fazendo com que se comportem de acordo com os valores internos do grupo. Não existem regras escritas e as sanções ao comportamento inadequado não são explícitas. No entanto, 
estas podem incluir o afastamento ou isolamento por parte do grupo e até prejuízo para a carreira do militar.

Toda família militar é, isso inclui todas as famílias de militares, espera-se, num círculo militar, que todos mantenham um certo estilo, acho que isso aí vem caminhando junto com o próprio comportamento de militar. Entende? Então, quando, às vezes, desvirtua alguma coisa assim, as coisas ficam complicadas. ${ }^{46}$

Então, a esposa passa a ser uma extensão do trabalho, com compromissos familiares, com uma série de coisas, que se fosse um trabalho civil não teria. E esse contato com outras esposas acaba não gerando uma cobrança nossa. Mas você sabe que a mulher cobra mais da outra mulher, do que o homem. Então, às vezes há uma cobrança muito grande por parte do círculo, e não nossa, por expectativa nossa. ${ }^{47}$

No que tange esse aspecto do que se espera da esposa, é que o meio militar ele é formal. Então, se uma esposa, por exemplo, ela se comporta de uma maneira inadequada, naturalmente, ela se comporta de uma maneira inadequada, naturalmente, ela vai chamar a atenção. E as pessoas tendem a se distanciar dela. Essa é a realidade que pode ocorrer. ${ }^{48}$

$\mathrm{Na}$ medida em que a regulamentação e as sanções encontram respaldo no grupo, este demonstra legitimidade e eficácia simbólica, e pode, a partir disto, ter uma atuação política. "Na medida em que um projeto social represente algum grupo de interesse, terá uma dimensão política, embora não se esgote a esse nível, pois sua viabilidade política propriamente dependerá de sua eficácia em mapear e dar sentido às emoções e sentimentos individuais." (VELHO, 1999, p.33. Grifos do autor)

A Família Militar passa a ter uma dimensão política no momento em que se coloca na defesa pública de seus membros. Uma vez impedidos, por regulamentos internos, de participarem em protestos públicos, os militares contam com suas esposas e outros membros de suas famílias como porta-vozes de suas reivindicações. Entidades como a União Nacional das Esposas de Militares das Forças Armadas (UNEMFA), a Associação Nacional das Esposas de Militares das Forças Armadas (ANEMFA) e a Associação de Pensionistas e Esposas dos Militares das Forças Armadas (APEMFA) têm como principal objetivo organizar essas mulheres para protestar contra a atual situação salarial dos membros das Forças Armadas.

No mês de janeiro de 2008, a UNEMFA, a entidade com maior nível de representatividade, preparou um protesto contra a paralisação das negociações sobre o reajuste salarial que os militares receberiam neste ano. A paralisação e a subsequente revisão das negociações foram provocadas pela rejeição da Contribuição Provisória sobre Movimentações Financeiras (CPMF) e a consequente necessidade de reorganizar o orçamento da União para 2008. O reajuste que os militares receberiam foi visto, naquela ocasião, como um dos principais alvos de corte para o reequilíbrio da contabilidade nacional. No dia 31 do mesmo mês, foi realizado o que se chamou de "Dia de Manifesto da Família Militar”, uma manifestação (panelaço) de cerca de cem pessoas, em frente ao 
Palácio do Planalto que exigia o cumprimento por parte do governo das propostas feitas anteriormente.

Cumpre salientar, que este tipo de manifestação política não conta com o apoio de todo o grupo, nem com a aprovação de todos os oficiais e chega a enfrentar resistência nos altos escalões militares. Este fato - a pouca "eficácia em mapear e dar sentido às emoções e sentimentos individuais" (VELHO, 1999, p.33) - demonstra que a representação política não é a principal forma de atuação e legitimação da Família Militar. Sua principal característica é fomentar o apoio e a colaboração entre seus membros, além de incentivar o zelo pelos valores militares. Percebemos este tipo de atuação como fundamental para minorar os transtornos causados pelas exigências específicas da profissão militar e para manter a coesão interna do grupo.

Portanto, conforme vimos, existe nos meios militares uma adesão feminina, que pode se dar em maior ou menor grau, aos valores que os oficiais são estimulados a adquirir em seu processo de socialização profissional. Esta adesão leva à formação de casais que possuem um projeto comum, que se realiza por meio da carreira do marido. Neste sentido, ambos reconhecem que o papel desempenhado pela esposa - dar apoio, cuidar dos filhos e do lar, na maior parte das vezes, abdicando de projetos pessoais - é fundamental para o sucesso deste objetivo. Esta percepção é imprescindível para que a esposa sinta-se valorizada e gratifica-a pelos sacrifícios pessoais que realiza. Para minorar as dificuldades impostas pelas exigências específicas da profissão militar, as esposas passam a formar a chamada Família Militar, que é eminentemente percebida como fonte de apoio e instância de manutenção e zelo pelos valores militares.

\section{Referências Bibliográficas}

CARVALHO, Marilu. Caminhando com Estrelas... Brasília: Thesaurus, 2008.

CASTRO, Celso. O espírito militar: um antropólogo na caserna. Rio de Janeiro: Jorge Zahar Ed., 2004.

FERREIRA, Oliveiros. Vida e morte do partido fardado. São Paulo: Ed. SENAC São Paulo, 2000.

GOFFMAN, Erving. Manicômios, prisões e conventos. São Paulo: Perspectiva, 2003.

SARACENO, Chiara. "A dependência construída e a interdependência negada. Estruturas de gênero da cidadania”. In BONACCHI, Gabriela; GROPPI, Ângela. O dilema da cidadania: direitos e deveres das mulheres. São Paulo: Editora da Universidade Estadual Paulista, 1995.

SILVA, Fernanda Machado Chinelli. "Eu adoro ser mulher de militar”. Estudo exploratório sobre a vida das esposas de militares. p.08. Disponível em:

<<http://www.abed-ddfesa.org/page4/page7/page21/files/FernandaChinelli.pdf >>

SINGLY, François de. Sociologia da família contemporânea. Rio de Janeiro: Editora FGV, 2007. 
TAKAHASHI, Emília Emi. Homens e mulheres em campo: um estudo sobre a formação da identidade militar. Tese , Unicamp, 2002.

THOMPSON. Paul. A voz do passado: História Oral. Rio de Janeiro: Paz e Terra, 1992.

\author{
VELHO, Gilberto. Individualismo e cultura. Notas para uma antropologia da sociedade \\ contemporânea. Rio de Janeiro: Jorge Zahar Ed., 1999.
}

\title{
NOTAS
}

${ }^{1}$ Além destas entrevistas foram realizadas entrevistas e conversas informais com membros e ex-membros das Forças
Armadas que não figuram aqui como documentação para este artigo. Umas das dificuldades encontradas em se
pesquisar uma instituição fechada é justamente a realização das entrevistas. Por vezes, elas precisam ser autorizadas
pelo comando, a escolha dos entrevistados acontece mais por designação do que por oferecimento voluntário e as
declarações tendem a ser feitas no sentido de minimizar as possíveis implicações negativas das falas para a corporação.
${ }^{2}$ Consideramos que o processo educacional pelo qual passa um indivíduo para se tornar um oficial militar utiliza muitas
das características valorizadas na socialização masculina, tais como a força, o exercício da liderança e a capacidade de
domínio, portanto, buscamos compreender como se realiza esta formação e quais são as características específicas
valorizadas dentro deste procedimento. Acreditamos, também, que a forma como os cadetes são socializados sofreu
pouca ou nenhuma variação ao longo do período estudado, principalmente no que se refere aos seus valores específicos. Por isso, as considerações feitas aqui serão utilizadas para todo o período pesquisado.

${ }^{3}$ Segundo Oliveiros Ferreira "a hierarquia e a disciplina - que se transformaram num segundo hábito pelo treinamento e são o cimento da estrutura militar - permitem a cada um que entra em ação saber que a obediência às ordens é a condição para que" esta seja bem sucedida. (FERREIRA, 2000, p.24).

${ }^{4}$ Referimos-nos aqui ao requisito da observância e obediência aos princípios da disciplina e da hierarquia. Sua desconsideração pode levar, em última instância, a "um desrespeito ao que estatuem leis e regulamentos militares, mas também se alterar o quadro mental, o espírito que norteia e que, em geral, é tido como típico das Forças Armadas" (FERREIRA, 2000, p.21). O autor refere-se aqui à problemática em torno dos conceitos de "responsabilidade individual" e "obediência devida".

5 De acordo com Celso Castro (2004, p.14) são fornecidos aos cadetes, "no próprio local de estudo, moradia, alimentação, uniformes, serviço de lavanderia e assistência médica e dentária, além de um pequeno soldo."

${ }^{6}$ Os alunos são oficialmente considerados cadetes após a matrícula, que ocorre ao término do período de adaptação.

${ }^{7}$ Nas palavras de um cadete, em conversa informal: "Se você percebe que está fazendo alguma coisa (atividade) sozinho, pode saber que está fazendo algo errado."

${ }^{8}$ Existe, neste caso, uma identificação entre os rituais praticados nas academias militares e nas universidades brasileiras. Nestas, os "bixos" - com grafia que também indica diferenciação - recebem tratamento semelhante ao dos cadetes ingressantes. Neste caso, porém, este ritual de passagem possui uma importância simbólica menor.

9 Em última instância, de acordo como Oliveiros Ferreira, o sentimento de honra deve criar no militar uma "ligação patética", emocional, que comove a alma, com a Pátria e a sua defesa. Para esta pesquisa, no entanto, interessa determinar quais são as características, valores e atitudes que o militar adquire em seu processo de socialização e utiliza para se relacionar com o meio civil. (FERREIRA, 2000, p.26).

${ }^{10}$ Utilizamos aqui a definição dada por Gilberto Velho: "uma sociedade na qual a divisão social do trabalho e a distribuição de riquezas delineiam categorias sociais distinguíveis com continuidade histórica, sejam classes sociais, estratos, castas. Por outro lado, a noção de complexidade traz também a ideia de uma heterogeneidade cultural que deve ser entendida como a coexistência, harmoniosa ou não, de uma pluralidade de tradições cujas bases podem ser ocupacionais, étnicas, religiosas etc.” (grifo do autor) (VELHO, 1999, p.16)

${ }^{11}$ Definido como "ação com algum objetivo predeterminado" (grifo do autor). (VELHO, 1999, p.26)

${ }^{12}$ Estamos trabalhando com a ideia de que todo indivíduo está imerso em um contexto histórico e, portanto, sujeito a suas determinações, sendo que seus projetos estarão submetidos aos mesmos pressupostos.

${ }^{13}$ Entrevista concedida pelo Subtenente Martins em 22/02/2008. Grifo nosso.

${ }^{14}$ Entrevista concedida pelo Subtenente Martins em 22/02/2008.

${ }^{15}$ Entrevista concedida pelo Coronel Miranda em 21/02/2008.

${ }^{16}$ Entre os entrevistados, percebemos uma diferença nos discursos, tanto de maridos como das esposas, entre aqueles que são oficiais superiores (dois Coronéis e suas esposas) e aqueles que são oficiais intermediários (dois Capitães e seus cônjuges) e oficiais subalternos (uma Tenente e seu marido). Acreditamos que estas diferenças se devam a: $1^{\circ}$ ) maior tempo de permanência na instituição no caso dos primeiros (os oficiais "antigos"); $2^{\circ}$ ) Por serem mais velhos, os dois primeiros casais estariam mais sujeitos às determinações dos estereótipos e atitudes de gênero descritos anteriormente, enquanto as expectativas em relação às características demonstradas pelos demais casais seriam mais flexíveis; $3^{\circ}$ ) Os 
demais oficiais citados pertencem aos Quadros Complementares, ou seja, não são militares de carreira e, portanto, estão sujeitos a um menor número de transferências e não aspiram aos postos do topo da hierarquia militar.

${ }^{17}$ Entrevista concedida por Érica, esposa do Coronel Miranda, em 21/02/2008.

${ }^{18}$ Entrevista concedida pelo Coronel Miranda em 21/02/2008.

${ }^{19}$ Entrevista concedida pelo Subtenente Martins em 23/02/2008.

${ }^{20}$ Entrevista concedida por Moysés, marido da Capitão Eduarda, em 21/02/2008.

${ }^{21}$ Entrevista concedida pelo Coronel Miranda em 21/02/2008.

${ }^{22}$ Entrevista concedida pelo Subtenente Martins em 22/02/2008.

${ }^{23}$ Entrevista concedida por Érica, esposa do Coronel Miranda, em 21/02/2008.

${ }^{24}$ Idem.

25 "Não, eu o conheci, ele ainda era rapazinho, ele não era militar nem nada. Mas claro que a escolha da profissão dele, isso fortaleceu mais o relacionamento também, e porque a gente vê que é uma pessoa que tem uma conduta séria que um militar tem que ter. Então, eu acho que isso ajuda muito." Entrevista concedida por Carolina, esposa do Coronel Oliveira, em 20/02/2008.

${ }^{26}$ Idem.

${ }^{27}$ Entrevista concedida pela Tenente Camila em 21/02/2008.

${ }^{28}$ Entrevista concedida pela Capitão Eduarda em 21/02/2008.

${ }^{29}$ Entrevista concedida por Carolina, esposa do Coronel Oliveira, em 20/02/2008.

${ }^{30}$ Entrevista concedida por Luiza, esposa do Capitão Mercaldo, em 20/02/2008.

${ }^{31}$ Entrevista concedida por Carolina, esposa do Coronel Oliveira, em 20/02/2008.

${ }^{32}$ Uma explicação complementar seria a aplicação da fórmula expressa por Singly (2007, p.150): "O casal é a cabeça, os braços e o coração são as mulheres", que se refere a casais em que as decisões mais importantes são tomadas conjuntamente e as concernentes ao cotidiano, pela esposa. Neste sentido, o compartilhamento das grandes decisões seria uma forma de afirmar a igualdade do casal. Entretanto, no caso militar com as especificidades da profissão, podemos ressalvar que, acrescido a isto, existe a percepção de que ambos estão sujeitos às decisões da instituição.

${ }^{33}$ Entrevista concedida por Carolina, esposa do Coronel Oliveira, em 20/02/2008. Grifo nosso.

${ }^{34}$ Entrevista concedida pelo Subtenente Martins, esposa da Tenente Camila, em 22/02/2008.

${ }^{35}$ Importa destacar que nas esposas mais velhas, esta adesão é ainda maior. Podemos perceber isso neste depoimento de uma esposa de General. "Ao aceitar o convite de amigas para escrever um testemunho vivido durante "minha vida no Exército", achei que seria um livreto, onde outras mulheres também colocariam suas impressões sobre esse período, mas sem grandes pretensões, seria apenas uma gostosa conversa entre amigas, uma maneira de relembrar um tempo que nos marcou tanto. E marcou tanto, por quê? Foram 42 anos vividos dentro de "uniforme verde-oliva". E confesso que, até hoje, 58 anos depois, eu e Armando não despimos, ainda, esse verde-oliva, porque não entramos nele, ele entrou em nós." (CARVALHO, 2008, p.129)

${ }^{36}$ Entrevista concedida pela Capitão Eduarda em 21/02/2008.

${ }^{37}$ Entrevista concedida pela Capitão Eduarda em 21/02/2008.

${ }_{38}^{38}$ Entrevista concedida por Carolina, esposa do Coronel Oliveira, em 20/02/2008.

${ }^{39}$ Entrevista concedida por Luiza, esposa do Capitão Mercaldo, em 20/02/2008.

${ }^{40}$ Entrevista concedida por Érica, esposa do Coronel Miranda, em 21/02/2008.

41 "Esse é um aspecto bastante difícil. Para você ter uma idéia, eu tenho 23 anos de casado e 27 mudanças. Uma, às vezes mais, por ano. Em um ano, eu já mudei 2 ou 3 vezes de casa." Entrevista concedida pelo Coronel Oliveira em 20/02/2008.

${ }^{42}$ Entrevista concedida pelo Capitão Mercaldo em 20/02/2008.

${ }^{43}$ Este é um grupo prioritariamente feminino. Embora participem das atividades promovidas pelo grupo, os maridos passam boa parte do tempo "em serviço" e, além disso, têm a oportunidade de estabelecer um número maior de contatos nas diferentes esferas sociais que suas funções lhes permitem acesso. Sendo assim, as mulheres constituem a força preponderante neste espaço.

${ }^{44}$ Entrevista concedida pela Tenente Camila em 22/02/2008.

${ }^{45}$ Entrevista concedida pelo Coronel Oliveira em 20/02/2008.

${ }^{46}$ Entrevista concedida pelo Subtenente Martins em 23/02/2008.

${ }^{47}$ Entrevista concedida pelo Capitão Mercaldo em 20/02/2008.

${ }^{48}$ Entrevista concedida pelo Coronel Miranda em 21/02/2008.

Artigo recebido em 10/2010. Aprovado em 11/2010. 